doi:10.18575/msrs.sm.e.15.03

UDC: 618.3-008.6-07

COBISS.RS-ID 5325336

\title{
The Combined Screening Test in the First Trimester of Pregnancy and Preeclampsia
}

\section{ABSTRACT}

Introduction: The combined screening test in the first trimester of pregnancy and determination of biochemical markers, pregnancy-associated plasma protein-A (PAPP-A) and free beta subunit of human chorionic gonadotropin (free B-hCG) were measured to assess the risk for developing hypertensive disorders during pregnancy after 20 weeks of gestation. Preeclampsia (PE) is the leading cause of maternal and fetal morbidity and mortality.

Aim of the study: To present obtained results of biochemical markers (PAPP-A and free B-hCG) taken from a serum of pregnant women with preeclampsia in the first trimester of pregnancy and to examine the correlation between biochemical markers, age of the pregnant woman and body mass index (BMI) with preeclampsia.

Patients and methods: This retrospective study included 70 pregnant women in two groups: (1) preeclampsia group ( $n=40)$, (2) control group $(n=30)$.

Results: In the preeclampsia group, the mean value of free B-hCG was 37.18 \pm 20.64 IU/L and for PAPP-A 2711.15 $\pm 1788.60 \mathrm{mIU} / \mathrm{L}$ with a statistical significance of $p=0.007$, compared to the control group. The mean value of body mass index (BMI) was $26.18 \pm 4.93 \mathrm{~kg} / \mathrm{m}^{2}$ and for age $31.53 \pm 5.00$ years. In the control group, the mean value of free B-hCG was 29.97 $\pm 10.39 \mathrm{IU} / \mathrm{L}$ and for PAPP-A $3411.30 \pm 1227.59 \mathrm{mlU} / \mathrm{L}$. The mean value of body mass index (BMI) was $23.47 \pm 4.09 \mathrm{~kg} / \mathrm{m}^{2}$ and for age of pregnant women $28.10 \pm 4.57$ years.

Conclusion: There is a significant association between the low level of biochemical marker PAPP-A in serum and the risk for PE. The difference of values of free B-hCG between the groups tested was not statistically significant. Maternal age and body mass index (BMI) are confirmed risk factors for development of PE.

The combined screening test contributes to the prevention of PE, with the goal of improving health of pregnant women.

Keywords: preeclampsia, pregnancy-associated plasma protein-A, free beta subunit of human chorionic gonadotropin

\section{Aleksandra Đorđević ${ }^{1}$, Dragica Draganović ${ }^{2}$}

${ }^{1}$ Institute of Laboratory Diagnostic ${ }^{2}$ Clinic of Gynecology and Obstetrics University Hospital Clinical Centre, Banja Luka, Republic of Srpska

\section{Contact address:}

Aleksandra Đorđević

Zavod za laboratorijsku dijagnostiku

Univerzitetska bolnica

"Klinički centar" Banja Luka, 12 beba bb, $780 o o$ Banja Luka, Republika Srpska

tel.+38766535770

e-mail:vitkosanda@yahoo.com
Submitted: June 26th, 2015 Accepted: July 6th, 2015 


\section{Introduction}

Preeclampsia is the dominant, representative form of hypertensive disease in the pregnancy, characterized by the presence of high blood pressure after 20 weeks of gestation, appearance of edema and proteinuria, with the completed healing process in the first six weeks after birth. The incidence of preeclampsia is in the range of $2-8 \%$, depending on diagnostic criteria. The predisposing risk factors for preeclampsia are: pregestational diabetes mellitus, chronic kidney disease, pregestational hypertension - existing hypertension, obesity, nulliparous, pregnant women younger than 18 and older than 35 years, preeclampsia in previous pregnancy, molar pregnancy, multiple pregnancy, thrombophilia and fetal hydrops. Some risk factors may appear before or during pregnancy. ${ }^{1}$

Beside regular controls of a pregnant woman (blood pressure, body weight and other risk factors) and fetus, the prevention of PE is presented by the specific activities and measures in accordance with the recommendations of the Guideline for the health care of women during pregnancy. ${ }^{1-3}$

Owing to preventive measures, we would be able to reduce the incidence of preeclampsia and accompanying complications, which would contribute to improving health of pregnant women.

\section{Aim of the study}

The aims of the study are:

1. to determine the results of biochemical markers (PAPP-A and free beta-hCG) from serum of pregnant women with preeclampsia in the first trimester of pregnancy,

2. to determine the correlation between biochemical markers (PAPP-A and free beta-hCG), age and body mass index (BMI) in pregnant women with preeclampsia.

\section{Materials and Methods}

This paper represents a retrospective analysis which included 70 pregnant women classified in two groups. The first group consisted of pregnant women with preeclampsia $(\mathrm{n}=40)$, with the average age of $31.53 \pm 5.00$, and the second, control, group consisted of healthy pregnant women $(n=30)$, with the average age of $28.10 \pm 4.57$.

The criteria for inclusion of pregnant women in our study were defined by the Guideline for the health care of women during pregnancy and it was confirmed by clinical and laboratory measurings. ${ }^{1,2}$ All pregnant women did the combined screening test in the first trimester of pregnancy from 12th to 14th week of gestation at the Institute of Laboratory Diagnostic of the University Hospital Clinical Centre Banja Luka in the period from September 2011 to September 2013.
The combined screening test is used for the early detection of risk for chromosomal abnormalities (trisomies 21, 18 and 13) in prenatal diagnosis and includes measuring of biochemical markers PAPP-A and free beta-hCG from the serum, and ultrasound parameters (nuchal translucency thickness, NT, and crown-rump length, CRL ).4-6

In the group with preeclampsia, the youngest pregnant woman was 21 and the oldest 46 years old. In the control group, the youngest pregnant woman was 20 and the oldest 38 years old. Biochemical markers (PAPP-A and free beta-hCG) were measured from the sample of serum by using Electrochemiluminescen immunoassay (ECLIA) - "sandwich" technique, on Roche Cobas E601 analyzer. Later, based on the clinical examination and laboratory analysis, the first group of pregnant women $(n=40)$ was diagnosed with preeclampsia.

BMI within combined screening test in the first trimester of pregnancy was defined for all pregnant women. Obtained results of biochemical markers PAPP-A and free beta-hCG, BMI and age of pregnant women are presented with mean values \pm standard deviation (SD).

Statistical descriptive analysis of results and testing of variables in two groups of pregnant women were performed using Excel and SPSS program version 22.0. with nonparametric Spearman correlation coefficient (rho) and nonparametric tests (Mann-Whitney test and KolmogorovSmirnov test ).

Using logistic regression analysis we examined the influence of individual variables on the occurrence of preeclampsia. ROC curve analysis (Receiver Operating Characteristic) was conducted for biochemical markers PAPP-A and free beta-hCG, based on which the sensitivity and specificity of the tests are estimated.

\section{Results}

Descriptive statistics of analyzed parameters (concentrations of biochemical markers of the combined screening test in the first trimester of pregnancy PAPP-A and free betahCG, maternal age and BMI) are presented in Table 1 by the groups (a group of pregnant women with preeclampsia (PE) and the control group of healthy pregnant women).

Results of examined variables obtained by statistical data analysis between two groups of pregnant women, using nonparametric Mann-Whitney test and comparing their medians, were ranked and there was a statistically significant difference $(p<0.05)$ for variables such as age, BMI and biochemical marker PAPP-A. Values of variables are presented with $\mathrm{Z}$ - approximation and medium effect size $r(r=Z / \sqrt{ } n)$.

Mann-Whitney test did not found a statistically significant difference for the values of free beta-hCG between the 
Table. 1 Descriptive statistics of parameters examined

\begin{tabular}{|c|c|c|c|c|}
\hline $\begin{array}{l}\text { Group with PE } \\
(n=40)\end{array}$ & Age of pregnant women & $\begin{array}{c}\text { Body mass index } \\
\left(\mathrm{BMl}, \mathrm{kg} / \mathrm{m}^{2}\right)\end{array}$ & $\begin{array}{c}\text { Free } B-\text { hCG } \\
(I U / L)\end{array}$ & $\begin{array}{c}\text { Marker PAPP-A } \\
(\mathrm{mlU} / \mathrm{L})\end{array}$ \\
\hline Mean & 31.53 & 26.18 & 37.18 & 2711.15 \\
\hline Median & 31.00 & 25.71 & 33.00 & 2111.50 \\
\hline Minimum value & 21.00 & 20.15 & 7.00 & 555.00 \\
\hline Control group $(n=30)$ & Age of pregnant women & $\begin{array}{c}\text { Body mass index } \\
\left(\mathrm{BMl}, \mathrm{kg} / \mathrm{m}^{2}\right)\end{array}$ & $\begin{array}{c}\text { Free } B-h C G \\
(I U / L)\end{array}$ & $\begin{array}{c}\text { Marker PAPP-A } \\
(\mathrm{mlU} / \mathrm{L})\end{array}$ \\
\hline Mean & 28.10 & 23.47 & 29.97 & 3411.30 \\
\hline Standard deviation & 4.57 & 4.09 & 10.39 & 1227.59 \\
\hline Median & 28.00 & 22.61 & 31.00 & 3239.00 \\
\hline
\end{tabular}

group of pregnant women with preeclampsia and the control group of healthy pregnant women. The level of significance for free beta-hCG is $\mathrm{p}=0.291$, statistically not significant for the result $\mathrm{Z}$ (Table 2.).

Table 2. Statistical significance of examined parameters

\begin{tabular}{lcccc}
\hline & Age & $\begin{array}{c}\text { Body mass } \\
\text { index (BMI) }\end{array}$ & $\begin{array}{c}\text { Free } \\
\text { B-hCG }\end{array}$ & $\begin{array}{c}\text { Biomarker } \\
\text { PAPP-A }\end{array}$ \\
\hline $\begin{array}{l}\text { Mann-Whitney } \\
\text { test }\end{array}$ & 374.000 & 330.000 & 511.000 & 371.000 \\
\hline$Z$ & -2.689 & -3.205 & -1.057 & -2.718 \\
\hline $\mathrm{p}$ & 0.007 & 0.001 & 0.291 & 0.007 \\
\hline
\end{tabular}

By applying Kolmogorov-Smirnov test on our sample and by distribution analysis, we found a statistically significant difference between the groups for variables such as age $(\mathrm{p}=0.044)$, BMI $(\mathrm{p}=0.003)$ and biochemical marker PAPP-A ( $p=0.004)$. Kolmogorov-Smirnov test showed that free beta-hCG is not a statistically significant variable $(\mathrm{p}=0.397)$.

By using the model of logistic regression, we examined the effect of one or more variables (age, BMI, biochemical markers PAPP-A and free beta-hCG) on the occurrence of preeclampsia as a dependent, nominal and categorical variable with a statistical significance of $\mathrm{p}<0.05$. This model explains that the set of analyzed variables (model with 4 indicators) affects between 21.3\% (Cox \& Snell R Square) and $28.6 \%$ (Nagelkerke R Square) variances of probability for the occurrence of preeclampsia and correctly classifies $74.3 \%$ of cases. Logistic regression shows $\chi^{2}=16.74$ (4, $n$ $=70), p=0.002$. Sensitivity of the model was $77.50 \%$ or the percentage of pregnant women recognized by the model as truly positive; specificity was $70 \%$ or the percentage of pregnant women without preeclampsia recognized by the model as truly negative.
The positive predictive value (PPV) was $77.50 \%$ and negative predictive value (NPV) was 70.00\%. Ratio was $\mathrm{LR}+=2.58, \mathrm{LR}-=0.32$.

With the combination of biochemical markers and confirmed risk factors of preeclampsia, such as age and body mass index (BMI), by using the model of logistic regression their effect and a statistical significance change.

Biochemical markers PAPP-A and free beta-hCG were examined using ROC curve analysis (Receiver Operating Characteristic ) based on which the ratio of sensitivity and specificity of the test at different decision limits (cut-off values) is estimated.

Diagram 1. ROC curve for free beta-hCG

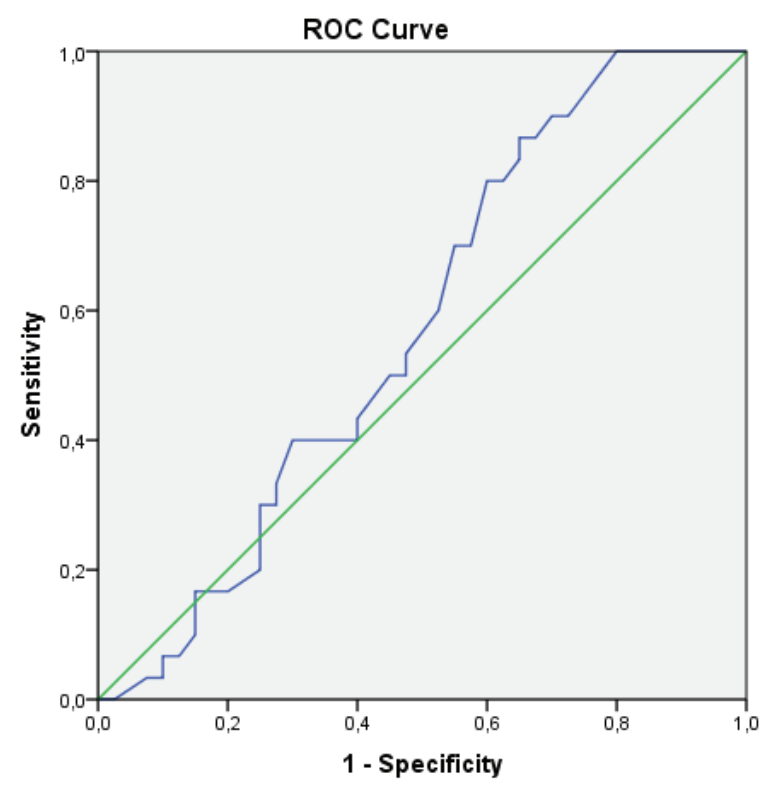

Diagonal segments are produced by ties. 
In the diagram (1.and 2.), truly positive results are presented on the $y$-axis and false- positive results on the $\mathrm{x}$-axis. The area under the ROC curve is about characteristics of the test and it presents a measure of diagnostic accuracy.

\section{Diagram 2. ROC curve for PAPP-A}

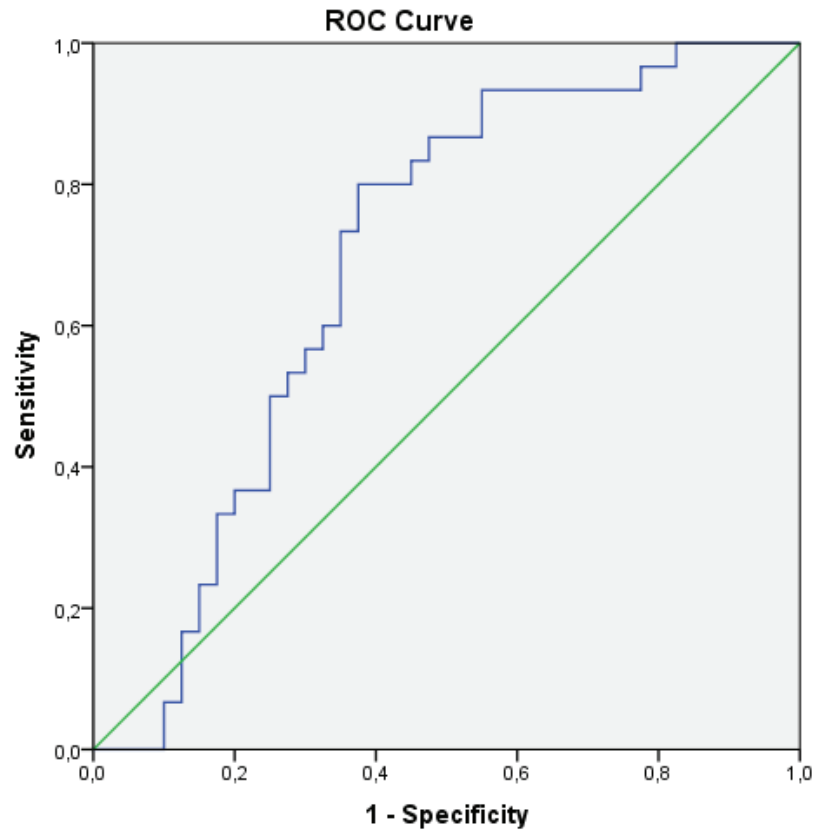

The area under ROC curve for PAPP-A is 0.691, $\mathrm{p}=$ 0.007. This shows that the test is statistically significant and classifies as a poor test (Diagram 2.). The ROC curve analysis for biochemical marker PAPP-A showed that the optimal cut-off presents the value of $2530.00 \mathrm{mIU} / \mathrm{L}$, has sensitivity of $80 \%$ and specificity of $63 \%$.

\section{Discussion}

Preeclampsia is a complex multisystematic and multifactorial syndrome specific for pregnancy. It is the leading cause of maternal and fetal morbidity and mortality.?

On a sample of 70 pregnant women, $40(57.1 \%)$ of them represents a group of pregnant women with preeclampsia and 30 of them (42.9\%) makes the control group of healthy pregnant women. Obtained results of biochemical markers during the combined screening test in the first trimester of pregnancy (free beta-hCG and PAPP-A) were presented in a form of concentration for the markers, while numerous studies that we used for comparison with our results describe parameters through the multiples of median (MoM), making the interpretation of markers difficult. We decided to use this way of presentation of results because of the nonhomogeneous and nonlinear distribution for the markers and because by using the SsdwLab v5,o programme for the combined screening test, the corrected multiple of median is calculated according to the data on pregnancy (e.g. age of pregnant woman, body mass index, presence of diabetes type I) and ultrasound markers for fetus (nuchal translucency thickness, NT, crown-rump length, CRL, gestational age of the fetus, GA).

Descriptive statistical data analysis of variables examined showed that pregnant women in the group with preeclampsia were older than healthy pregnant women from the control group ( $31.53 \pm 5.00$ vs. $28.10 \pm 4.57)$, they had higher BMI $\left(26.18 \pm 4.93 \mathrm{~kg} / \mathrm{m}^{2}\right.$ vs. $23.47 \pm 4.09 \mathrm{~kg} /$ $\mathrm{m}^{2}$ ), higher concentration of biochemical marker free betahCG (37.18 $\pm 20.64 \mathrm{IU} / \mathrm{L}$ vs. 29.97 $\pm 10.39 \mathrm{IU} / \mathrm{L})$ and lower concentration of biochemical marker PAPP-A (2711.15 \pm $1788.6 \mathrm{mIU} / \mathrm{L}$ vs. $3411.30 \pm 1227.59 \mathrm{mIU} / \mathrm{L}$.)

Considering the absence of normal and linear distribution for the variables examined, we used, except for maternal age, non-parametric statistical tests, which do not take distribution into account. ${ }^{8,9}$

The youngest among pregnant women was 20 and the oldest 46 years old. The Mann-Whitney test confirmed that, for age, there is a statistically significant difference between the groups, $\mathrm{Z}=-2.689, \mathrm{r}=0.321, \mathrm{p}=0.007$.

By conducting statistical analysis of the age of pregnant women and examining correlations with other variables, we found a statistically significant correlation with body mass index (BMI) $p=0.008$ and the occurrence of preeclampsia $\mathrm{p}=0.006$. In the control group, the age of pregnant women had positive and moderate correlation with free beta-hCG ( $p=0.021$ ) and negative and moderate correlation with marker PAPP-A $(\mathrm{p}=0,011)$, with the level of statistical significance $\mathrm{p}=0.05$.

Our results are in accordance with the data from the literature stating that hypertension in pregnancy is more common in older pregnant women and, by the model of logistic regression of individual variables, this risk factor is very important for the development of preeclampsia. It was only for age, as an examined variable, that we had a normal distribution, which is in accordance with other authors. ${ }^{1,3}$

Numerous studies specify obesity as a risk factor for preeclampsia. ${ }^{10,11}$

In our results, using correlation data analysis, body mass index (BMI) was confirmed as a statistically significant (p $<0.05$ ). In the preeclampsia group there was a negative, moderate and statistically significant correlation between BMI and biochemical markers, PAPP-A $(p=0.028)$ and free $\beta-h C G(p=0.014)$ while in the control group of healthy pregnant women there was a marginally significant and negative correlation with marker PAPP-A $(p=0.057)$.

Mann-Whitney test confirmed a statistically significant difference for the body mass index and that it is more 
important in relation to other examined variables, $\mathrm{Z}=$ - 3.205, $r=0.383, p=0.001$. According to KolmogorovSmirnov test, the BMI has a statistical significance, $\mathrm{p}=$ 0.003 .

The model of logistic regression of individual variables showed the age of pregnant women as more important risk factor for the prediction in comparison with the body mass index. New studies suggest the prevention of obesity prior to conceiving, that is, planning of pregnancy, because $\mathrm{PE}$ can be a risk factor for cardiovascular, cerebrovascular and/or other chronic diseases later in life. ${ }^{11,12}$ During the combined screening test in the first trimester of pregnancy between the 12th and 14th week of gestation, biochemical markers (free B-hCG and PAPP-A) secreted by the trophoblastic cells of placenta were determine from the serum of pregnant women.

Free $\beta$ - hCG often has false positive values greater than 2.0 $\mathrm{MoM}$, and it requires a necessary correct interpretation and determination of the correlation between its value and the state of pathological pregnancy. ${ }^{4-6}$ Data from the literature show that increased levels of hCG, regardless if the total or free B-hCG subunit is being measured, are indicators of fetal hypoxia. Higher levels of free $B-h C G$ (> 2.5 MoM) can also indicate the risk of preeclampsia. ${ }^{6}$

In our results, free $\beta-$ hCG in the preeclampsia group of pregnant women was increased but it was not statistically significant, according to Mann-Whitney test $(\mathrm{p}=0.294)$ and Kolmogorov-Smirnov test $(\mathrm{p}=0.397)$.

The ROC curve analysis (Receiver Operating Characteristic) for the free B-hCG marker found that the test was bad and not statistically significant $(\mathrm{p}=0.291)$ because of the small area under the ROC, AUC $=0.574$.

Numerous studies have examined the effect of biochemical marker PAPP-A on the assessment of the course and outcome of pregnancies with a diagnosed threatened preterm labour and PE. Some studies describe connection between the low values of biochemical marker PAPP-A, less than $10 \%$, with SGA (Small for Gestational Age ) and PE. ${ }^{12,13}$

A study conducted by Lončar, et. al. determines the values of concentration of biomarker PAPP-A between the 11th and 13th week of gestation. Pregnant women diagnosed with preeclampsia in all gestational ages had statistically significant lower values of biomarker PAPP-A in comparison with healthy pregnant women. ${ }^{14}$

Our results showed lower values of biomarker PAPP-A in the group of pregnant women with preeclampsia, compared to the control group of pregnant women ( Table.1).

By using Spearman's correlation coefficient (rho), MannWhitney test, Kolmogorov-Smirnov test and the ROC cur- ve analysis for biochemical marker PAPP-A, our study confirms the correlation of the biomarker and PE, as well as its statistical significance. According to the MannWhitney test, biomarker PAPP-A is statistically significant, $\mathrm{Z}=-2.718, \mathrm{r}=0.325, \mathrm{p}=0.007$.

Low value of biochemical marker PAPP-A in the FASTER study was defined as the value of this marker obtained by the screening test in the first trimester of pregnancy $\leq$ $5 \%(\leq 0.4 \mathrm{MoM})$ while the value $\leq 5 \%$ in SAMSAS 2012 study was $\leq 0.37 \mathrm{MoM}$ and this cut-off is relevant for South Australia. ${ }^{15}$ The recommendation of this study is about the necessity of informing a pregnant woman about complication risks regarding the low values of PAPP-A marker. The goals of health protection during pregnancy include follow-up of health status of pregnant women and fetus, timely identification of high-risk pregnancies and giving support with adequate advice and information in accordance with the recommendations of the Guideline for the health care of women during pregnancy. ${ }^{2}$ All this leads to better communication and trust between pregnant women and their gynecologists, as well as their education about possible risks, which improves health of pregnant women and fetus.

The analysis of the ROC curve (Receiver Operating Characteristic) for biochemical marker PAPP-A showed the area under the ROC curve of 0.691 (95\% CI $=0.566$ to 0.816$), p=0.007$. This confirms that this variable is statistically significant but classified as a "poor" test.

When we take all this into account, we could expect that pregnant women with low values of biochemical marker PAPP-A, measured during the combined screening test in the first trimester of pregnancy, should be, apart for the risk of trisomies 21, 18 and 13 for which screening the test is being conducted, followed up as high-risk pregnancies for the development of PE and its complications (threatened preterm labour, $\mathrm{PE}$, placental abruption, intrauterine growth restriction). ${ }^{11,12,16}$

These pregnant women should be controlled every four weeks after the 2oth week, until the 3oth week of pregnancy even more often, if there are signs of preeclampsia. ${ }^{15}$

With an appropriate prevention we could reduce the incidence of morbidity and mortality of pregnant women and fetus, that is, pregnancy complications.,16 The use of selected markers is also cost-effective in clinical application when it comes to the price and providing the most optimal diagnostic information. ${ }^{17}$ The application of a well-planned screening test in the prevention of disease is cheaper in comparison to the costs of treating already affected patients.

Given the results of our study and confirmed correlations between variables, a combination of examined risk factors 
such as age, body mass index (BMI), together with the combined screening test in the first trimester of pregnancy and the use of Doppler blood vessels of the uterus, contributes to the prevention of $\mathrm{PE}$ and improves maternal health. ${ }^{1,3,12,18 .}$

\section{Conclusion}

The age of pregnant women is a statistically significant risk factor for the development of $\mathrm{PE}$ with a negative and medium significant correlation with PE. The BMI has a predictive value for the occurrence of PE and we found negative and moderately significant correlation with biochemical markers and PE. Prevention of obesity as a risk factor for the development of PE is an integral part of the overall prevention of this disease. Statistical significance between the groups examined was not confirmed for free $B$-hCG. Our results showed significantly lower values of marker PAPP-A in the group of pregnant women with PE compared to the control group and also confirmed the correlation between the low PAPP-A value and the risk of developing PE. The combined screening test in the first trimester of pregnancy for the early detection of chromosomal abnormalities trisomies 21, 18 and 13 is of great importance in the prevention and early detection of high-risk pregnancy for preeclampsia.

\section{References}

1. D. Draganović, Korelacija markera oksidativnog stresa sa morfološkom analizom posteljice kod hipertenzije u trudnoći, Doktorska disertacija, Univerzitet u Banjoj Luci, Medicinski fakultet, Banjaluka, 2014.

2. Republička stručna komisija za izradu i implementaciju vodiča u kliničkoj preksi, Nacionalni vodič za lekare u primarnoj zdravstvenoj zaštiti, Zdravstvena zaštita žena u toku trudnoće, Ministarstvo zdravlja Republike Srbije, Srpsko lekarsko društvo, 2005.

3. N. Katsiki, D. Godosis, S. Komaitis, A. Hatzitolios, Hypertension in pregnancy: classification, diagnosis and treatment, Aristotle University of Thessaloniki, Medical Journal, Vol. 37, Issue 2, June 2010.

4. D. Lončar, S. Lončar, Prenatal diagnostics, Acta Medica Medianae 2008; 47(2): 58-66.

5. D. Lončar, Credibility of the combined test in prenatal diagnostics, GENETIKA,Vol. 43, No.2, 2011; 285-296. http://dx.doi. org/10.2298/GENSR1102285L

6. J. Durković, L. Anđelić, B. Mandić, D. Lazar, False positive val- ues of biomarkers of prenatal screening on chromosomopathy as indicators of a risky pregnancy, J Med Biochem 30. 2011; 126130. http://dx.doi.org/10.2478/v10011-011-0010-x

7. A. Jakovljević, M. Bogavac, A. Nikolić, J. Suđi, Importance of early detection of uric acid, creatinine and urea in serum and amniotic fluid in preeclampsia, Glasilo Podružnice Srpskog lekarskog društva Zaječar, Vol. 37: Broj 4, 2012.

8. J. Pallant, SPSS Priručnik za preživljavanje, Mikro knjiga, Beograd, 2011.

9. J. C. Sheridan, SPSS verzija 20, Analiza bez muke, Kompjuter biblioteka, Wiley, 2013.

10. J. M. Roberts, L. M. Bodnar, T. E. Patrick, R. W. Powers, The Role of Obesity in Preeclampsia, Pregnancy Hypertens. 2011; January 1; 1 (1): 6-16.

11. H. Itoh, N. Kanayama, Obesity and Risk of Preeclampsia, Med J Obstet Gynecol, 2014; 2 (2): 1024.

12. A. Pilalis , A.P. Souka, P. Antsaklis, G. Daskalakis, N. Papantoniou, S. Mesogitis, A. Antsaklis, Screening for pre-eclampsia and fetal growth restriction by uterine artery Doppler and PAPP-A at 11-14 weeks' gestation, Ultrasound Obstet Gynecol. 2007; Feb; 29(2): 135-40. http://dx.doi.org/10.1002/uog.3881 PMid:17221926

13. C. Andrade, J. Santos, A. Rita Pinto, P. Manso, S. Pereira, FirstTrimester Biochemical Markers and Small-for-GestationalAge Infants, Acta Med Port 2014; Mar-Apr: 27(2): 191-195. PMid:24813486

14. D.Lončar,M.Varjačić,S.Arsenijević,Significanceofpregnancy-associated plasma protein A ( PAPP-A) concentration determination in the assessment of final outcome of pregnancy, Vojnosanit Pregl 2013; 70(1): 46-50. http://dx.doi.org/10.2298/VSP110530023L PMid:23401929

15. Clinical Guideline, South Australian Perinatal Practice Guidelines - Management of women with a low PAPP-A and normal chromosomes, Department of Health, Government of South Australia, ISBN number : 978-1-74243-062-1, 2014.

16. A. Grdinić, A. Grdinić, Hypertensive syndrome in pregnancy how to predict, MATERIA MEDICA, Vol. 29, No. 2, 2013.

17. N. M. Singh, S. Ignjatović, R. Kovačević, M.Ilić, N. Lalić, Diagnostic and prognostic significance of biomarkers, Jugoslov. Med. Biohem. 21: 2002; 1-7, http://dx.doi.org/10.2298/JMHo201001M

18. L. P. Peshev, N. A. Lyalichkina, G. V. Fominova, Risk Factors and Uterine Artery Doppler in the Prediction of Placental Insufficiency in the First Trimester of Pregnancy, Department of obstetrics and gynecology, Mordovian state Universities named N.P. Ogarev, Saransk, Russia, Americal Journal of edical Sciences and Medicine, 2013; Vol.1. No.4, 69-74. 


\section{Kombinovani skrining test u prvom tromjesečju trudnoće i preeklampsija}

\section{SAŽETAK}

Uvod: Kombinovani skrining test u prvom tromjesečju trudnoće i određivanje biohemijskih markera, plazma protein A vezan za trudnoću (PAPP-A) i slobodna podjedinica beta-horionskog gonadotropina (free B-hCG) u serumu, su mjereni za procjenu rizika za razvoj hipertenzivnog poremećaja tokom trudnoće poslije 20 nedjelje gestacije. Preeklampsija (PE) je vodeći uzrok maternalnog i fetalnog morbiditeta i mortaliteta.

Cilj rada: Predstaviti rezultate biohemijskih markera (PAPP-A i slobodna B-hCG) u serumu u prvom tromjesečju trudnoće kod trudnica sa PE i utvrdi povezanost između biohemijskih markera, starosne dobi i indeksa tjelesne mase (BMI) sa preeklampsijom. Ispitanici i metode: Retrospektivnom analizom je obuhvaćeno 70 trudnica u 2 grupe: (1) grupa sa preeklampsijom ( $n=40)$, (2) kontrolna grupa $(n=30)$.

Rezultati: U grupi trudnica sa PE srednja vrijednost za slobodnu B-hCG je 37,18 $\pm 20,64$ IU/L, a za PAPP-A 2711,15 $\pm 1788,60$ $\mathrm{mIU} / L$ sa statističkom značajnošću $p=0,007$, u odnosu na kontrolnu grupu. Srednja vrijednost indeksa tjelesne mase ( BMI ) je $26,18 \pm 4,93 \mathrm{~kg} / \mathrm{m}^{2}$ i starosna dob trudnica $31,53 \pm 5,00$ godina. U kontrolnoj grupi trudnica srednja vrijednost za slobodnu B-hCG

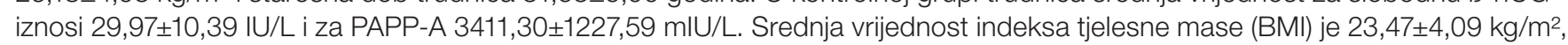
dok za starosnu dob trudnica iznosi $28,10 \pm 4,57$ godina.

Zaključak: Postoji značajna povezanost između niske vrijednosti biohemijskog markera PAPP-A u serumu i rizika za PE. Razlika slobodne B-hCG između ispitivanih grupa nije statistički značajna. Starosna dob trudnica i indeks tjelesne mase (BMI) su potvrđeni faktori rizika za razvoj PE.

Kombinovani skrining test doprinosi prevenciji PE, sa ciljem unapređenja zdravlja trudnica.

Ključne riječi: preeklampsija, plazma protein A vezan za trudnoću i slobodna podjedinica beta-horionskog gonadotropina 